\title{
Characteristics of Student Critical Thinking in Solving Microbiology Problems
}

\author{
Aminuddin PP \\ Faculty of Teaching and Education \\ Universitas Lambung Mangkurat \\ aminuddinpatra@gmail.com
}

\author{
Baitun Nikmah \\ Faculty of Teaching and Education \\ Universitas Lambung Mangkurat \\ niemahbaitun@gmail.com
}

\begin{abstract}
Critical thinking is an intellectual process that actively and conceptually conceptualizes, implements, analyzes, synthesizes, and evaluates information gathered or generated from observation, experience, reflection, reasoning, or communication, to guide beliefs and actions. The purpose of this study is to describe the characteristics of the students' critical thinking level in solving valid and reliable microbiological problems. The type of this research is descriptive research using qualitative approach. Subjects in this study were 4 students of Biology Education, Universitas Lambung Mangkurat academic year 2014/2015, taken from high, medium, and low category based on the students' score of microbiology course. Data analysis techniques used include data reduction, data presentation and draw conclusions. The results of this study indicate that based on its characteristics, at a less critical level, the students are able to understand the problem and prepare the plan of completion by fulfilling the reasoning element, the critical level enough for the students to understand the problem, to prepare and implement the problem solving plan by fulfilling the element of reasoning. Characteristics at a critical level are being able to understand problems, develop plans, implement problemsolving plans and re-examine problem-solving outcomes by fulfilling some logical elements except the elements of reasoning and inference and at a very critical level students are being able to understand problems, plan, implement problem-solving plans and review the problem-solving results based on the elements of reasoning. Students who take the course of microbiology certainly have different characteristics based on a written assignment that has been given.
\end{abstract}

Keywords_critical thinking, problem solving

\section{INTRODUCTION}

One of the main goals of higher education is having expertise through scientific reasoning based on logical, critical, systematic, and innovative thinking. But in reality, the instruction in courses given by most lecturers to students has not been able to develop critical thinking skills. In accordance with the objectives of the biology learning subject, the character of the nation is expected to emerge through biological learning, such as critical thinking and scientific attitude, namely being objective, open, tenacious, and able to cooperate with others. In this regard, MoNE, stated that science education should be conducted with scientific inquiry to foster thinking ability. The ability of one's thinking cannot be equated because each individual has a different ability profile.

Profile as an outline depends on how to look at it. This is consistent with [1] who states that a profile is a view of a person. Ref [2] also explains that profiles are graphs, diagrams, or writings that describe a state that refers to a person's / something's data. Characteristic is a special feature that is seen in a person

According to some research results, students' thinking ability in Indonesia is mostly low. Research by [3] shows that students' thinking ability in Mathematics Education Department of Mathematics and Natural Sciences UNNES in solving math problems has not reached the fourth level of thinking ability (very critical) and most of students still have low critical thinking ability. Research by [4] indicates that the critical thinking skills of students majoring in mathematics education in the subject of calculus 1 material limit algebra function are classified low. Research by Fithriyah (2016) shows that critical thinking ability of grade IX-D students SMPN 17 Malang is low because students are less able to understand the problem well. Hidayanti's research (2016) shows that students' critical thinking ability is also still low especially on indicators of analysis, evaluation, and inference. Ref [5] shows that each critical thinking indicator under study is in a less critical category.

One of the factors causing education failure in building nation character is educator. Students of Biology Education Faculty of Universitas Lambung Mangkurat as prospective educators must be aware that they have a very strategic role in the formation of the next generation of the nation. Educating is not only limited to knowledge transfer, but educating can change or shape the character of learners to be better, more polite and ethical in everyday life.

Universitas Lambung Mangkurat is one of the largest universities in South Kalimantan. ULM has several study programs, one of the other study program is Biology Education Faculty of Teacher Training and Education. Students of Biology Education Program have knowledge about microbiology. Microbiology is a branch of biology and 
compulsory subjects for biology teacher candidates in educational institutes of education (LPTK), especially in Biology Education Program Faculty of Teacher Training Education Universias Lambung Mangkurat Microbiology Course has a very complex material features because it is about studying on the origin microbial, prokaryotic, and eukaryotic microbes to their application and role to human life.

Students who take the course of microbiology certainly have different critical thinking profiles based on the experiences they have gained during lectures. It is known from the data of initial test results where each student has a different way of critical thinking in solving a problem, seen from the level of critical thinking of students in solving a microbiological-related problems of written assignment. It is based on the preliminary test on some students consisting of 3 persons selected by the researcher to represent the whole sample by giving written assignment. Then an assessment is done to classify the students into each level according to the characteristics of the Critical Thinking Solving of Microbiology Problems (BKPMM). From the preliminary test results, there are one student who belonged to BKPMM 3 (critical) and 1 belonging to BKPMM 2 (quite critical) and 1 person belonging to BKPMM 1 (less critical). The data shows that the picture / profile of critical thinking of ULM students is quite critical (data can be seen in appendix 1). This shows that the level of critical thinking owned by students is still not maximized. It can be identified by providing questions of written tasks that have been made to reveal the level of critical thinking of students in learning Microbiology.

Problem solving is an attempt by a person to solve problems by using the knowledge, skills and understanding he/she has. Ref [5] states that through the provision of the problem, a person's critical thinking ability can be traced properly. According to [6], there are 3 kinds of components, namely (1) reasoning elements, (2) intellectual standards of reason and (3) intellectual character reasoning. Reasoning [7] consists of 8 elements. The first is purpose. To understand a concept, one must be able to clearly define a goal. Question, as the second element, is an attempt to answer the question that the problem can be done by describing something. Next is attempt to identify assumptions clearly and determine whether they are accountable and how they form a point of view. The point of view is made with attention to various points of view so as to provide various alternative solutions. The next element is Information thinking which is used to identify information (data and facts), ensuring that the information used is clear and relevant to the question. Concepts are also the element which express ideas such as definitions, theories, principles, rules and models. In this case it is necessary to identify the concept and explain it. Subsequently, inference is from the withdrawal of conclusions or interpretations that illustrate the conclusions and give an understanding of the conclusions. Last, implication reasoning will have implications and consequences. It is therefore important to discover the implications and consequences of a reasoning and search for its negative and positive implications and consider the possible consequences.

Problem solving is an attempt by a person to solve problems by using the knowledge, skills and understanding he/she has. Ref [5] states that through the provision of the problem, a person's critical thinking ability can be traced properly. Based on the background that has been described, it is necessary to conduct research with the title "Student Critical Thinking Profile in the Solving of Microbiology Problem" related in an effort to improve the quality of science / biology teacher to answer the challenge of global competition in the world of education.

\section{METHOD}

This research is descriptive research using qualitative approach that describes the level of critical thinking. The type of descriptive-qualitative research aims to describe the event that becomes the center of attention (critical thinking of students) descriptively and based on qualitative data.

Subjects in this study are students of S-I Biology Education Universitas Lambung Mangkurat who has taken the course of Microbiology. The subjects were taken based on microbiology course grades classified into high, medium and low category. Instruments used to obtain, process and analyze data in this study are a written task profile on level of critical thinking and written assignment. The researchers developed a written task that is adapted to the steps of problem solving and the attainment of critical reasoning thinking elements.

The data generated in this study were analyzed using Miles and Huberman data analysis technique. The data were obtained from the assessment of students' answers to the question of written tasks. From the answer, the achievement of the element of reasoning could be seen. Thus, the level of critical thinking of each student can be obtained from the achievement of the reasoning elements.

\section{RESUlTS AND DisCUSSION}

\section{A. Research Results}

The results of written tasks that have been done by the students of Biology Education Faculty of Universitas Lambung Mangkurat, at each level of critical thinking are presented in Table 1.

TABLE 1. CRITICAL THINKING LEVEL OF MICROBIOLOGICAL PROBLEM SOLVING

\begin{tabular}{|c|c|c|c|c|c|}
\hline \multirow[t]{2}{*}{ No. } & \multirow[t]{2}{*}{ TBKPMM } & \multicolumn{2}{|c|}{ Students' Critical Thinking } & \multirow{2}{*}{\multicolumn{2}{|c|}{ DS }} \\
\hline & & $\mathrm{RN}$ & $\mathrm{RH}$ & & \\
\hline \multirow[t]{3}{*}{1.} & TBKPMM 1 & $\checkmark$ & & & \\
\hline & TBKPMM 2 & & & & \\
\hline & TВKРMM 3 & & & & \\
\hline 4. & TBKРMM 4 & & & & $\checkmark$ \\
\hline
\end{tabular}

\section{B. Discussion}

Characteristics of critical thinking in solving microbiological problems in this study are seen from the level 
of critical thinking in microbiological problem solving (BKPMM) achieved by the research subjects. The critical thinking component includes 8 elements of reasoning, namely objectives, information, questions, assumptions, concepts / ideas, point of view, implications and inference. Each element consists of 7 intellectual standards of reasoning, namely clear, precise, thorough, relevant, deep, broad and logical.

Based on the data from the results of comparing two written assignments done by four students, one student is at the level of BKPMM 1 (less critical), one person is at the level of BKPMM 2 (quite critical), one person at the level of BKPMM 3 ( critical), and the other person is at the level of BKPMM 4 (Very critical) From both written assignments done by the students, the result of the critical thinking level of students is confirmed valid and reliable.

Student RN has not been able to carry out the problemsolving plan and re-examine the outcome of the problem, since the element of reasoning has not been met. Based on these characteristics, students who are at this level have been able to solve problems related to microbiological information. It can be seen about the poor quality of microbes contained in the ice snack of school children. This is due to the low awareness of hygiene and sanitation of PJAS, and the limited water supply and infrastructure that do not meet the water cleanliness requirements used for drinking water.

One of the factors that influence it is the understanding of concepts. Student RN's score in the course is still low, so the level of critical thinking is also low. This is in accordance with the research of $\mathrm{K}-\mathrm{Choa} \mathrm{Yu}$, et al which states that the wrong theoretical knowledge when owned by someone will affect the person's ability to interpret the information, thus also influencing the judgment decision they make. This is also reinforced by [8] who states that low critical thinking causes learners unable to understand the application of the science concept, even though they already know the concept.

Based on the characteristics of critical thinking on Student $\mathrm{RH}$, it is found that the student has been able to solve the problems associated with the concept of microbiology. This can be seen when the student is able to make assumptions in microbiological problems by cooking water first before use in order to kill the bacteria in the water. This is in accordance with [3] research which explains that the level of this ciritical thinking can be synchronized with initial thinking because students at this level begin to modify their thinking ability such as identifying problems, recognizing relationships, finding relevant and appropriate concepts, and using analogy in solving problems. This is demonstrated by the reasoning that still does not meet clear and logical standards, as well as the point of view which is unclear and not widespread (marked the use of an analogy that is not developed according to the situation given to the problem solved).

Characteristics of critical thinking of Student AF are being able to understand the problem by fulfilling the element of reasoning of information, able to arrange problem solving plan by fulfilling both element reasoning assumption and concept / idea, able to execute problem solving plan by fulfilling element of reasoning point of view and also able to recheck problem solving result with fulfilling the element of reasoning implication. At this level, only one reasoning element is still not achieved, namely inference. Based on these characteristics, students who are at this level have been able to solve the problems associated with the concept of microbiology.

Based on the critical thinking characteristics of Student DS, the student is able to solve problems related to microbiological concepts up to re-examine the results of problem solving. This can be seen from the results of answers during interviews to questions. "What concepts are related to the subject matter of microbiology, then how can you solve the problem?" The student replied, "The related concept is a negative microbial or very harmful to health. Microbes are very dependent on dirty environments, especially on unhealthy snacks that children usually like. E. coli might be also spread in the dirty environment. Therefore, children should avoid this by healthy life style, such as not to drink or eat foods that contain microbes".

Based on the students' answers, it is clear that the student is able to connect unhealthy snack problems with the concept of microbiology that exist in the environment. Students as subjects in this study have been able to solve the microbiological problems that have been given. Students have been able to relate problems on the discourse with the concept of microbiology. Students from each level of critical thinking exhibit different characteristics. It can be seen from the achievement of reasoning elements and intellectual standards of students' reasoning from each level of critical thinking. Students who have a good understanding of microbiology concepts will make them able to solve microbiological problems with critical thinking. This is in line with the discovery of [4] who states that one of the factors that influence students' critical thinking is the mastery of the concept of the problem and the prerequisite material (initial concept), and its application. This means that students who are able to solve microbiology problems with critical thinking, have a good understanding of microbiological concepts.

The concept of microbiology is given as one of the courses to the students of Biology Education FKIP Universitas Lambung Mangkurat in the semester V. After completing the course of microbiology, students are expected to be able to use microbiology principles in solving problems related to microorganism in daily life, either personally as well as in work environment related to education. Biology education students as future educators are required to have a good understanding of microbiological concepts, in order to provide the basic principles of microbiology to learners. The basic acceptable principle that learners need to understand about the concept of microbiology is having the habit of hygienic lifestyle to avoid microorganisms that can infect the body. This is consistent with the findings of [9] which concluded that there is a significant influence between the critical and 
low thinking ability of students' affective, psychomotoric, and cognitive achievements on the microbiology material. Students who have a high level of critical thinking in solving microbiological problems will also have a good understanding of the concept of microbiology.

\section{CONCLUSION}

This research suggests several characteristics in solving microbiological problems. The less quality of critical thinking is influenced by the understanding of concepts. This finding can be seen from Student RN. It might be supported by the fact that Student RN's score in the course is still low, so the level of critical thinking is also low. Students with fair critical thinking are able to solve the problem until the stage of implementing the problem solving plan, but have not been able to recheck the results of the problem resolution. This can be seen when students are able to make assumptions in microbiological problems by cooking water first before use, in order to kill the bacteria in the water. Students' thinking is classified as critical when they have been able to solve problems related to the concept of microbiology and re-examine the results of problem resolution although one element of reasoning is still not fulfilled. Students who are at very critical level have been able to solve problems related to the concept of microbiology by fulfilling all the elements of reasoning.

\section{REFERENCES}

[1] H. Alwi, KBBI, third edition, Jakarta: Balai Pustaka, 2007

[2] V. Neufeld, Webster's New World College Dictionary Third Edition, USA, 1996

[3] A.W. Kurniasih, Penjenjangan Kemampuan Berpikir Kritis Mahasiswa Prodi Pendidikan Matematika FMIPA UNNES dalam Menyelesaikan, 2010

[4] H.O. Bempah, I. Sumarno and L. Yahya, Analysis of Critical Thinking Skills Mathematics Student Department of Mathematics Education at Calculus I Course Material Limit Function, Department of Mathematics Education Faculty of Mathematics and Natural Sciences, State University of Gorontalo, 2014, p. 3

[5] Maguna, Amrullah, Darsikin, and M. Pasaribu, "Ability of Critical Thinking of Student Candidate for Master in Electrical Material (Descriptive Study on Student of Physics Education Study Program of Tadulako University Year 2014), Journal of Physics Education Tadulako (JPFT) Vol. 4 No. 3, 2016, pp 1-5.

[6] P. Richard, Critical Thinking in Every Domain of Knowledge and Belief, Diakses melalui http://www.criticalthinking.org/pages/criticalthinking-in-every-domain-of-knowledge-and-belief/698, 2007.

[7] P. Richard \& L. Elder, The Thinker's Guide to Intellectual Standard, Diakses melalui http://www.criticalthinking.org/pages/universalintellectual-standards/527, 2008

[8] L.G. Synder dan M. J Synder, Teaching Critical Thinking and Problem Solving Skills, Spiring/Summer, (L2), 2008.

[9] M.W Ardhi, Biology Learning Through Guided Inquiry Model Using Mind Map Technique and Modified Roudhouse Diagram Technique in terms of Critical Thinking Ability and Skills of Student Science Process, Postgraduate Program of Sebelas Maret University Surakarta, 2012. 